\title{
“COMPLY OR EXPLAIN" IN THE EU, OR THE NEW HUMAN RIGHTS REPORTING OBLIGATION: AN ANALYSIS OF DIRECTIVE 2014/95/EU
}

\author{
EL PRINCIPIO "CUMPLIR O EXPLICAR” EN LA UNIÓN \\ EUROPEA, O LA NUEVA OBLIGACIÓN DE DIVULGAR \\ INFORMACIÓN SOBRE DERECHOS HUMANOS: UN ANÁLISIS \\ DE LA DIRECTIVA 2014/95/UE
}

\author{
Joseba Fernández GazTeA \\ M.S. in Foreign Service, Georgetown University \\ Personal Docente e Investigador en Formación (PhD Candidate) \\ Universidad de Navarra \\ Alberto Muñoz FernándeZ \\ Profesor Contratado Doctor de Derecho internacional privado \\ Universidad de Navarra
}

Recibido: 03.01.2017 / Aceptado: 10.01.2017

DOI: https://doi.org/10.20318/cdt.2017.3622

\begin{abstract}
This article aims to offer an interdisciplinary perspective in regard to EU Directive 2014/95. It caters to the interests of development experts and legal experts. An analysis of the Directive constitutes a micro-view on the wider issue of business-human rights. The analysis provides a chance to reflect upon wider development implications. The first half of this article deals with the development character of the Directive and its connection to business-human rights narratives. The second half offers a legal analysis of its precepts.

Keywords: disclosure, non-financial information, business and human rights, development, corporate social responsibility.

Resumen: Este artículo ofrece una perspectiva multidisciplinar sobre la Directiva 2014/95/UE, de interés tanto para los juristas como para los especialistas en desarrollo. El análisis de la Directiva constituye un estudio sobre un aspecto concreto en el campo de los negocios y los derechos humanos. Además, pone de manifiesto las implicaciones que esta norma tiene en el ámbito del desarrollo. Esta cuestión se abordará en la primera parte del artículo, junto con contextualización de la Directiva dentro de las corrientes actuales en el sector de los negocios y los derechos humanos. La segunda parte ofrece un análisis del articulado de la norma.
\end{abstract}

Palabras clave: divulgación, información no financiera, negocios y derechos humanos, desarrollo, responsabilidad social corporativa.

\footnotetext{
* Alberto Muñoz has developed this work within the framework of the EU Action Grant "Business and Human Rights Challenges for Cross-Border Litigation in the EU”, JUST/2013/JCIV/AG/4661.
} 
Sumary: I. Introduction. II. Multinational Corporations and Human Rights. III. Introduction to and developmental character of the Directive. IV. Two relevant issues. 1. A development case sustaining the Directive? 2. Narratives underlying the Directive. V. Legal commentary on the Directive. 1. Purposes of the Directive. 2. Target companies of the Directive. 3. Obligations of the companies. 4. Monitoring the fulfilment of the obligations. 5. Assessment. VI. Conclusion.

\section{Introduction}

1. This article presents a European viewpoint on the subject of business-human rights. Such a viewpoint is provided through the analysis of a human development tool: Directive 2014/95/EU (the 'Directive'). The Directive has to be implemented by national law by each of the $28 \mathrm{EU}$ member States by 6 December 2016 .

2. Given the existing correlation between human rights and development ${ }^{1}$, the mutual reinforcement that they exert on each other ${ }^{2}$, and the need to facilitate mutual understanding between development and human rights-legal camps ${ }^{3}$, an analysis of the Directive is relevant. Building on recent analy-

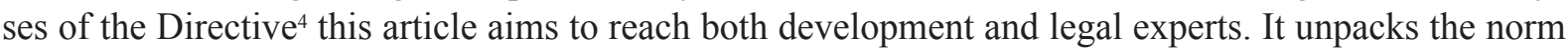
for the development-oriented reader while underscoring its developmental character for the legal expert. The suggestion for development-oriented readers is that the Directive is a development device codified in the specific language of EU law. A legal approximation is, therefore, unavoidable. The suggestion for legal experts is that above and beyond the legal intricacies they should not ignore the development gist of the norm and should conduct their analysis accordingly. A purely legal commentary on the precepts of the Directive in Section 4 is balanced with an introductory commentary in Section 3 on two extra-legal issues. These are: (i) the development perspective of the Directive, and; (ii) the conceptual linkage of the Directive to one of several existing narratives on the subject of human rights and business.

3. This article is not intended as an in-depth discussion yielding concrete answers to the issues raised, but rather as one of the first panoramic descriptions of the Directive. The breadth of its scope shall prove a valid starting point for further, more profound inquiry and reflection.

\section{Multinational Corporations ${ }^{5}$ and Human Rights}

4. The vast majority of multinational corporations do not engage in practices or relations with states that may lead to human rights abuses. "In general, they [multinationals] are unlikely to act in a manner that deliberately seeks to violate fundamental human rights". In fact, private sector financing and the activity of multinationals have helped lift millions out of poverty ${ }^{7}$. Multinational corporations can contribute to a human rights favourable environment by means of their great capacity to "create wealth,

\footnotetext{
1 D. P. ForsYthe, "Human Rights and Development: A Concluding View", in D. P. Forsythe (ed.), Human Rights and Development. International Views, St. Martin's Press, New York, 1989; D. KaufmanN, "Human Rights and Governance: The Empirical Challenge", in P. Alston / M. Robinson (eds.), Human Rights and Development. Towards Mutual Reinforcement, Oxford University Press, Oxford, 2005, pp. 352-402.

2 P. Alston / M. Robinson, "Human Rights and Governance: The Empirical Challenge", in P. Alston / Robinson, M. (eds.), Human Rights and Development, op. cit., pp. 1-18.

3 Idem.

${ }^{4}$ D. Kinderman, "Corporate Social Responsibility - der Kampf um die EU Richtlinie”, WSI Mitteilungen 8/2015, pp. 613621; D. G. Szabó / K. E. Sørensen, "New EU Directive on the disclosure of non-financial information", Nordic \& European Company Law Working Paper, No. 15-01, 2015.

5 We use the terms multinational corporations, transnational corporations and corporations interchangeably.

${ }^{6}$ P. MuChlinSKI, "Human rights and multinationals: is there a problem?", International Affairs, $\mathrm{n}^{\circ}$ 77(I), 2001, pp. 31-47.

7 United Nations Human Rights CounciL, "Report of the Working Group on the issue of human rights and transnational corporations and other business enterprises", UN Doc A/HRC/29/28, 2015.
} 
jobs and income, to finance public goods, and to generate innovation and development in many areas relevant to human rights and environmental protection, including medicine, food production, and environmental-friendly technologies". They can promote a form of development "...oriented towards the expansion of human capabilities, of which human rights are both a main ingredient and a precondition". Yet multinational corporations, "acting alone or in complicity with states, pose a real threat of violating a whole range of civil, political, social, economic and cultural human rights in diverse ways"10. Given this dual character, the relationship that multinational corporations entertain vis-à-vis human rights is a complex one ${ }^{11}$. The threat that multinational corporations' wrongdoing poses to human rights is particularly acute due to the transformation in the institutional features of the world economy ${ }^{12}$. In a context of increasing integration of a market-dominated global economy, transnational activity has increased nota$b^{1} y^{13}$. Concurrently with this economic growth, transnational corporations' rights have also grown ${ }^{14}$. Thus, transnational corporations have assumed an ever-greater power over the conduct of human affairs ${ }^{15}$. Such a power is secured by current trade and investment frameworks, for these frameworks still "hold considerable regulatory power that has not yet been fully harnessed to promote human rights objectives"16; this, despite the fact that recently the inclusion of responsible business conduct has become a dominant practice $^{17}$. Multinational corporations can, therefore, cause significant negative impacts on human rights. Online data facilitated by the Business \& Human Rights Resource Center web site reveals that in year 2015 approximately 280 corporations have been involved in allegations of human rights misconduct.

5. A plurality of works have analysed the human rights language and constraints of the foreign investment legal framework ${ }^{18}$, but fewer have attempted at offering an empirical-statistical assessment on the causal relationships between foreign direct investment and governance, social standards or human rights in host countries. Among these, Kaufmann examined the effect of first-generation human rights promotion on second-generation human rights. According to his understanding, political and civil rights matter significantly for the attainment of socio-economic developmental rights; there is a large direct causal effect from better governance to improved development outcomes ${ }^{19}$. Employing different variables Letnes analysed the opposite direction of causality; he studied the impact of foreign investment on human rights. He

\footnotetext{
8 University of Edinburgh, "Study of the Legal Framework on Human Rights and the Environment Applicable to the European Enterprises Operating Outside the European Union”, 2010. Available at

http://en.frankbold.org/sites/default/files/tema/101025_ec_study_final_report_en_0.pdf (accessed on 31 December 2016).

9 O. DE SChUtTER, "Transnational Corporations as Instruments of Human Development”, in P. Alston / M. RoBinson (eds.), Human Rights and Development. Towards Mutual Reinforcement, Oxford University Press, Oxford, 2005, pp. 403-444.

10 S. Deva, Regulating Corporate Human Rights Violations, Routledge, Oxon, 2012.

11 O. DE SCHUTter, “Transnational Corporations...", op. cit., 2005, pp. 403-444.

12 United Nations Commission on Human Rights, "Interim report of the Special Representative of the Secretary-General on the issue of human rights and transnational corporations and other business enterprises", UN Doc E/CN.4/2006/97, 2006.

13 C. Márquez Carrasco, "El plan nacional de España sobre empresas y derechos humanos y la implementación de los pilares proteger, respetar y remediar: oportunidades y desafíos", in C. MÁrquez CARRASCO (ed.), España y la implementación de los principios rectores de Naciones Unidas sobre empresas y derechos humanos: oportunidades y desafios, Huygens, Barcelona, 2014, pp. 25-53.

14 United Nations Commission on Human Rights (2006), op. cit.

15 J. A. Zerk, Multinationals and Corporate Social Responsibility, Cambridge University Press, Cambridge, 2006.

16 J. ForD, "Business and Human Rights: Bridging the Governance Gap", 2015. Available at https://www.chathamhouse.org/ sites/files/chathamhouse/field/field_document/20150922BusinessHumanRightsFordV2.pdf (accessed on 31 December 2016).

17 K. Gordon / J. Pohl / M. Bouchard, "Investment Treaty Law, Sustainable Development and Responsible Business Conduct: A Fact Finding Survey”, OECD Working Papers on International Investment, No. 1, 2014.

18 Please see: O. DE Schutter (ed.), Transnational Corporations and Human Rights, Hart Publishing, Puvimanasinghe, Oxford and Portland, 2006; A. ShemBerg, "Investment Agreements and Human Rights: The Effects of Stabilization Clauses", Corporate Social Responsibility Initiative Working Paper, No. 42, 2008; P. M. Dupuy / F. Francioni / E. U. Petersmann (eds.), Human Rights in International Investment Law and Arbitration, Oxford University Press, Oxford, 2009; M. JACOB, "International Investment Agreements and Human Rights", INEF Research Paper Series on Human Rights, Corporate Responsibility and Sustainable Development, No 3, 2010, and; K. Gordon / J. Pohl / M. Bouchard, op. cit.

19 D. Kaufmann, "Human Rights and Governance: The Empirical Challenge", in P. Alston / M. Robinson (eds.), Human Rights and Development. Towards Mutual Reinforcement, Oxford University Press, Oxford, 2005, pp. 352-402; D. KAufMAnN, "Human Rights, Governance and Development. An empirical perspective", in Development Outreach, 2006. Available at: http://siteresources.worldbank.org/EXTSITETOOLS/Resources/KaufmannDevtOutreach.pdf (accessed on 3 January 2017).
} 
found that "foreign direct investment can help generate economic growth and that this potential positive influence on the level of economic development can again have a positive influence on a host country's level of human rights". The manifestation of the investment effects on human rights depends -he contends- on the specific features of the multinational acting and on the host country characteristics ${ }^{20}$.

6. In face of this state of affairs, the risk is that the imbalance deepens between an increasingly large power of multinationals coupled with vulnerability of host societies and the precariousness of accountability. The risk is that the governance gap widens. It is against that risk and in furtherance of a long-term sustainable growth goal that the Directive was enacted as part of the wider European Union strategy on the business-human rights issue; a strategy including the provision of guidance and the development of national action plans in compliance of the EU Strategic Framework and Action Plan on Human Rights and Democracy ${ }^{21}$.

7. Within the available governance steering alternatives ${ }^{22}$, the EU expressly opted in the Directive for imposing a mandatory transparency - disclosure obligation of non-financial information including human rights. Various non-EU countries, including Australia, Canada, China, Indonesia, Malaysia, Norway and South Africa have done so too ${ }^{23}$. An obligation to report is, in principle, less likely to change corporate behaviour than stronger obligations such as the obligation to actually conduct social due diligence, the obligation to comply with social standards in public procurement, or the obligation of board directors to return part of their pay in case of social misconduct. Nevertheless, the reporting obligation contained in the Directive ought to be conceived as a pragmatic initial step that will enable further ones towards a more binding framework. This is consistent with the EU's option for the Ruggie-an "Protect, Respect and Remedy" framework put forward in the 2011 UN Guiding Principles on Business and Human Rights (the UN 'GPs') ${ }^{24}$. The EU has adopted the "principled pragmatism" approach underlying in the UN GPs. According to such approach, the option to further human rights respect and protection by businesses is to combine a set of non-excessively burdensome mandatory measures with a set of voluntary ones while traditional stronger international law binding rules develop. The aim is to start from general easily acceptable obligations and evolve then towards a more constringent legal frame.

\section{Introduction to and developmental character of the Directive}

8. In response to the European Parliament's request, the Commission submitted on April 2013 the Directive's initial legislative proposal as the culmination to a process. The background against which the Directive was conceived was primarily defined by two concerns. As per the Commission's resolutions

20 B. Letnes, Transnational Corporations, Economic Development and Human Rights: On the Importance of FDI Composition and Host Country Assets, Doctoral Thesis, 2008. Available at: http://www.diva-portal.org/smash/get/diva2:123924/ FULLTEXT01.pdf (accessed on 3 January 2017).

${ }^{21}$ H. Cantú Rivera, "The United Nations Guiding Principles on Business and Human Rights in the European Union. From Regional Action to National Implementation", in J. MARTiN / K. E. Bravo (eds.), The Business and Human Rights Landscape. Moving Forward, Looking Back, Cambridge University Press, New York, 2016, pp. 498-529; CounCIL OF THE EUROPEAN UNION, "EU Strategic Framework and Action Plan on Human Rights and Democracy", Council of the European document 11855/12, 2012. Available at http://www.consilium.europa.eu/uedocs/cms_data/docs/pressdata/EN/foraff/131181.pdf (accessed on 3 January 2017).

${ }^{22}$ These include: naming and shaming self-regulation, use of incentives, awards and accreditation systems, market-based initiatives, publication of league tables, allocation of private statutory rights, statutory compensation schemes, publicity and government-sponsored information and education campaigns.

${ }^{23}$ M. L. NARINE, "Living in a Material World - From Naming and Shaming to Knowing and Showing: Will New Disclosure Regimes Finally Drive Corporate Accountability for Human Rights?", in J. Martin / K. E. Bravo (eds.), The Business and Human Rights Landscape. Moving Forward, Looking Back, Cambridge University Press, New York, 2016, pp. $219-253$.

24 European Commission, Joint Communication to the European Parliament, the Council, the European Economic and Social Committee and the Committee of the Regions "A renewed EU strategy 2011-2014 for Corporate Social Responsibility", COM (2011) 681 final, 2011; European COMmission, "Commission Staff Working Document on Implementing the UN Guiding Principles on Business and Human Rights - State of Play”, SWD (2015) 144 final, 2015. 
and the Directive itself these were, (i) a long-term necessity to provide the conditions for sustainable economic growth through social justice and environmental protection (Directive, Whereas 3), and (ii) a shorter-term concern to rebuild trust in the performance of businesses given the increasing social attention focusing on the social and ethical behaviour of enterprises in the current economic crisis environment ${ }^{25}$. Two additional facts complete the background against which the Directive was formulated. Firstly, the increasing economic significance of transnational corporations and global supply chains ${ }^{26}$. Secondly, the "increasingly important role played by human rights, the rule of law and democracy" in the EU ${ }^{27}$.

9. Furthermore, the Directive is an instrument aimed at fostering the EU's human development goal. An EU internal legal norm itself, the Directive is intended to pursue the goals set in EU development policy. The Directive targets fostering sustainable development and human rights protection, two conditions constituting the context in which the eradication of poverty and fulfillment of the Millennium Development Goals ought to take place ${ }^{28}$. These two goals were called to occupy a notable position in the EU development agenda as stated by the Commission ${ }^{29}$. The Directive will continue to pursue these ends in the post-2015 development agenda. Because the Directive involves key players in the private sector in the pursuance of sustainable development through human rights protection, it contributes to develop the framework set for the attainment of the 2030 vision: rights-based, people centered action targeting at the eradication of poverty through the interplay of the three dimensions of sustainable development, i.e. social, environmental and economic ${ }^{30}$.

\section{Two Relevant Issues}

10. With a view to raising awareness of the development facet of the Directive, two extra-positivistic issues shall be examined prior to proceeding to a legal commentary.

This section deals with two considerations, namely, (i) the developmental perspective to the Directive, and; (ii) the conceptual linkage of the Directive to one of several existing narratives on the issue of human rights and business.

\section{A development case sustaining the Directive?}

11. Essentially, by virtue of the Directive, corporations need to increase their reporting by including a new section containing information about their performance in and impact on, environmental, social, human rights, anti-corruption and bribery matters. If a corporation does not pursue policies in relation to any of these matters, it must provide a clear and reasoned explanation for not doing so.

25 European Commission, Joint Communication to the European Parliament, the Council, the European Economic and Social Committee and the Committee of the Regions "A renewed EU strategy 2011-2014 for Corporate Social Responsibility", op. cit.

26 T. J. Bollyky / A. Bradfurd, "Getting to Yes on Transatlantic Trade Consistent US-EU Rules Could Remake Global Commerce", Foreign Affairs, 10 July, 2013. Available at https://www.foreignaffairs.com/articles/united-states/2013-07-10/getting-yes-transatlantic-trade (accessed on 3 January 2017).

27 M. Cremona, "Values in the EU Constitution: the External Dimension", Stanford Institute for International Studies Center on Democracy, Development, and the Rule of Law Working Paper, Number 26, 2004.

28 European Parliament Council Commission, Joint statement by the Council and the representatives of the governments of the Member States meeting within the Council, the European Parliament and the Commission on European Union Development Policy: "The European Consensus" (2006/C 46/01), The European Consensus on Development, para. 5.

29 European Commission, Communication from the Commission to the European Parliament, the European Economic and Social Committee and the Committee of the Regions "Increasing the impact of EU development Policy: an Agenda for Change", COM (2011) 637 final, 2011.

30 European Commission, Communication from the Commission to the European Parliament, the Council, the Economic and Social Committee and the Committee of the Regions "A Stronger Role of the Private Sector in Achieving Inclusive and Sustainable Growth in Developing Countries", COM (2014) 263 final; European Commission, Communication from the Commission to the European Parliament, the Council, the Economic and Social Committee and the Committee of the Regions "A decent Life for all: from vision to collective action", COM (2014) 335 final; EuropEAn CoMmission, "Commission Staff Working Document on Implementing the UN Guiding Principles on Business and Human Rights - State of Play”, SWD (2015) 144 final. 
12. The Directive states that the human rights regulations it implements contribute to attain a "sustainable global economy by combining long-term profitability with social justice and environmental protection" (Directive, Whereas 3). Individual company profitability is facilitated by the added value that its positive external social impact represents. In accordance with this, it is sound in long-term economic terms to embed sustainability into the DNA of the company. Following this argument, this is beneficial globally, there are no losers: neither the corporation applying this sustainability frame, nor the countries in which it conducts business are negatively affected.

13. But the following question arises: does the Directive take into account the developmental needs of the societies it will affect? Or, formulated in more tractable terms: how can the Directive better contribute to the developmental needs of the societies it will affect?

It is advisable that corporations be required to provide a development case taking into account the perspective of the countries in which such activities are carried out. The Directive would better serve its end of "managing change towards a sustainable global economy" through the monitoring of corporations' "impact on society" (Directive, Whereas 3 ) if it demanded that the following question be answered: 'How does this corporation contribute to meet the broader economic and social objectives of the particular society(ies) upon which it develops its business?'. This could be disentangled into a double requirement: asking corporations to ensure that their reporting tackles both (i) the specific situation and circumstances of the host countries affected, and (ii) the broader "structural dimensions of their presence" ${ }^{\prime \prime}$. Otherwise transparency risks being one that conveys a partial and inaccurate picture of corporations' impact.

14. The proposition that the specific situation and circumstances of the host countries affected be tackled refers to the need of taking into account the particular perspective of the affected societies in the reporting exercise. The notion of the "responsibility of enterprises for their impacts on society" ${ }^{32}$ can only be understood as the responsibility of enterprises for their impacts on a particular society for the abstract term 'society' can only become a reality in specific societies characterised by their particular features. The responsibility of corporations for their activity is always linked to a particular society or societies with specific traits and, therefore, a transparency-enhancing reporting measure inevitably has to incorporate their particular point of view.

15. The proposition that the broader structural dimension of the presence of corporations be tackled refers to the need of the reporting exercise to be one delivering an overall assessment of the presence of such a corporation. An assessment that responds to the question 'Beyond the answers the Directive is asking for from corporations, is the presence of that corporation conducive of the human development of the communities in which it operates ${ }^{33}$ ? If not, there exists the chance that the reporting reflects acceptable environmental, social, human rights, anti-corruption and anti-bribery accomplishments while avoiding mentioning broader potential negative impacts such as, for instance, the flight of wealth and capital and the crowding out of local producers and investors ${ }^{34}$. If this broader structural dimension is not dealt with, the reporting message may end being a distorted one. The underlying logic of the Directive -transparent information enabling consumers, investors and peers to exercise pressure on noncompliant corporations- would be undermined.

16. Though non-binding in character, the reporting guidelines to be prepared and published by the Commission before 6 December 2016 (Directive, Article 2) could drive towards the implementation

31 O. De SchutTer, “Transnational Corporations as Instruments of Human Development...”, 2005, op. cit., pp. 403-444.

32 European Commission, Joint Communication to the European Parliament, the Council, the European Economic and Social Committee and the Committee of the Regions "A renewed EU strategy 2011-2014 for Corporate Social Responsibility", COM (2011) 681 final, para. 3.1.

33 Expression used by de Schutter (O. DE SCHUTTER, "Transnational Corporations as Instruments of Human Development", op. cit., 2005, p. 408).

34 O. DE SchUtTER, “Transnational Corporations as Instruments of Human Development”, op. cit., 2005, pp. 403-444. 
of these suggestions. These need to recommend that the reporting be always qualified by the particularities of the society it is referring to, and that the elaboration on environmental, social, human rights, anti-corruption and bribery be one that interconnects all the issues and offers a broad assessment of the impact of their activities.

\section{Narratives underlying the Directive}

17. The Directive stems from a narrative on the human rights - business issue; a narrative arising from factors present in the 1960s and $1970 \mathrm{~s}^{35}$ which burst into global public consciousness in the $1990 \mathrm{~s}^{36}$. Such a narrative shares common ground and is related through constant interaction to conflicting narratives on the issue.

18. According to such a narrative, a socially embedded form of economic governance needs to be built in the current context of an increasingly diffused state authority. Within the polycentric, multi-layered system of international governance, developed-country multinational enterprises are the leading sources of foreign direct investment accounting for 84 per cent of global outflows ${ }^{37}$. As above explained, when insufficiently monitored or regulated, these "uniquely international, uniquely mobile and uniquely powerful" 38 members of global society tend to generate human rights violations of the host populations, especially in developing host states, either actively or as accomplices ${ }^{39}$. There exist difficulties when it comes to addressing these violations legally, owing to the inherent fragmentation of the international law system. Since a functionally integrated overarching legal scheme and language such as the global law and meta-language Domingo advocates ${ }^{40}$ does not exist, enforcement is a very difficult task, given the multiplicity of political and legal systems. For instance, problems with forum identification arise when addressing human rights violations by transnational businesses. In view of this challenge -the narrative goes-, the pragmatic, realistic and efficient way forward is to produce a smart mix of norms in which a set of basic mandatory measures and voluntary initiatives coupled with peer and consumer pressure over time may build an interest among leading firms for a more level playing-field vis-à-vis laggards, thereby ensuring political balance in the corporate sector and, eventually, leading to stricter legal obligations ${ }^{41}$. This approach, it is argued, is beneficial to corporations as it contributes to the sustainability of their activity. In addition, it does not preclude further 'traditional' state action, which ought to be conducted through "carefully crafted precision tools" completing and augmenting existing ones ${ }^{42}$.

19. But this particular CSR discourse in which the Directive is rooted on is not univocal, nor undisputed. CSR has been interpreted, for instance, as the battleground on which contesting actors (corporations, NGOs) conduct a strategic political struggle for their interests, and as the accommodating bargain resulting from this ${ }^{43}$. The option for the recognition in favour of corporations of a right-obligation to exert 'responsible' autonomy in human rights protection is also a matter of disagreement. Confronting the conception on which the Directive is based runs a counter argument based on the as-

35 P. Muchlinski, Multinational Enterprises and the Law, Oxford University Press, Oxford, 2007, p. 3.

36 R. Mares, "Business and Human Rights After Ruggie; Foundations, the Art of Simplification and the Imperative Cumulative Progress", in R. MAres (ed.), The UN Guiding Principles on Business and Human Rights, Martinus Nijhoff Publishers, Leiden, 2011, p. 44.

37 Ö. C. Kahale, "Project Finance and the Relevant Human Rights", in S. Leader / D. Ong (eds.), Global Project Finance, Human Rights and Sustainable Development, Cambridge University Press, Cambridge, 2011, p. 37.

38 S. Joseph, "Taming the Leviathans: Multinational Enterprises and Human Rights", Netherlands International Law Review, No 46, 1999, p. 176.

39 Ö. C. Kahale, op. cit., p. 37.

40 R. Domingo, The New Global Law, Cambridge University Press, New York, 2010.

41 R. MARes, op. cit., p. 29.

42 R. MARes, op. cit., p. 26.

43 D. L. Levy / R. Kaplan, "Corporate Social Responsibility and Theories of Global Governance", in A. Crane / A. McWilliams / D. Matten / J. Moon / D. S. Siegel (eds.), The Oxford Handbook on Corporate Social Responsibility, Oxford University Press, Oxford, 2008. 
sertion that "human rights concerns may be of such a fundamentally different magnitude, as compared with other corporate social responsibility issues, that they should never be entrusted to self regulatory responses" ${ }^{44}$. As enumerated by Gatto, a plurality of scholars stressing the 'ensure' function of human rights protection ${ }^{45}$ critically appraise voluntary initiatives ${ }^{46}$. A more binding framework -according to the counter reasoning- needs to be put in place ${ }^{47}$. As expressed by Kamminga, what is needed "...are binding international standards accompanied by strong enforcement machinery" ${ }^{18}$ since existing implementation mechanisms are "deficient or undeveloped"

\section{Legal Commentary on the Directive}

20. Having considered extra-legal aspects of the Directive, this section provides an overview of its legal aspects ${ }^{50}$.

\section{Purposes of the Directive}

21. The immediate purpose of the Directive is to increase the transparency of corporations in non-financial issues reporting. But this is only a means, the end is more ambitious, i.e. to contribute to a sustainable global economy. Corporations have often sought benefits in the short term, occasionally through unfair means. This is a factor that has contributed to the disregard of labour rights, environmental concerns and even human rights. Facing this challenge, the Directive aims to promote a "change towards a sustainable global economy by combining long-term profitability with social justice and environmental protection" (Directive, Whereas 3). Formally, the Directive's objective is to foster growth and deter corruption as well as to encourage a wider respect for human rights and the environment. According to this reasoning, transparency should lead corporations to better performance, lower financing costs, and the capacity to attract and retain talented employees ${ }^{51}$. This ought to make European companies competitive and sustainable, and, ultimately, contribute to human development through the creation of more jobs ${ }^{52}$.

22. One of the key matters in which the reporting obligations of the Directive should move corporations to better performance is human rights. It can be expected that the Directive not only will deter companies from committing human rights violations, but also will encourage them to adopt positive policies to support or promote their enjoyment. For this reason, although protection of human rights is not the primary objective of the Directive, it can become an effective mechanism for this purpose.

23. Through the pursuance of its immediate objectives, the Directive should result in an improvement of the business-human rights relation. To some extent, this is a common trait that the Di-

44 P. Muchlinski, Multinational Enterprises and the Law, op. cit., p. 525.

45 S. Joseph, "Taming the Leviathans: Multinational Enterprises and Human Rights", Netherlands International Law Review, No 46, 1999, p. 175.

46 A. Gatto, Multinational Enterprises and Human Rights. Obligations under EU Law and International law, Edward Elgar, Cheltenham, 2011, p. 15, footnote 46.

47 K. LuKas, "Human Rights in the Supply Chain: Influence and Accountability", in R. MARES (ed.), The UN Guiding Principles on Business and Human Rights, Martinus Nijhoff Publishers, Leiden, 2011, p. 165.

48 M. T. KammingA, "Holding Multinational Corporations Accountable for Human Rights Abuses: A Challenge for the EC", in P. Alston (ed.), The EU and Human Rights, Oxford University Press, Oxford, 1999, p. 568.

49 S. Deva, Regulating Corporate Human Rights Violations, Routledge, Oxon, 2012, p. 65.

50 See also R. Perea Ortega, "La Directiva 2014/95/UE sobre divulgación de información no financiera e información sobre diversidad por parte de determinadas grandes empresas y grupos", LA LEY mercantil, No. 15, 2015.

51 European Commission, "Disclosure of non-financial and diversity information by large companies and groups - Frequently asked questions", MEMO 14/301, 2014; please see S. K. PArK / G. Berger-Walliser, "A Firm-Driven Approach to Global Governance and Sustainability”, American Business Law Journal, No 52(2), 2015, pp. $271-275$.

52 European Commission, Statement "Improving corporate governance: Europe's largest companies will have to be more transparent about how they operate”, STATEMENT 14/124, 2014. 
rective shares with other CSR actions. Please note that this is a different approach to that of applying directly extraterritorial legislation and enforcement measures against human rights violations.

24. From a comparative perspective, the Directive shares a common assumption with the Global Reporting Initiative: reporting makes abstract issues tangible and concrete, thereby assisting in understanding and managing the effects of sustainability developments on the organization's activities and strategy ${ }^{53}$.

\section{Target companies of the Directive}

25. The Directive aims to establish obligations for corporations, i.e. large undertakings which are also public-interest entities exceeding the criterion of the average number of 500 employees on balance sheet during the financial year.

26. For the purposes of the Directive, public-interest entities are limited liability undertakings or those whose members are limited liability companies (Article 1 Directive 2013/34/EU), i.e. companies: a) governed by the law of a member State and whose transferable securities are traded in regulated markets of any member State; b) credit institutions; c) insurance undertakings; or, d) companies designated by member States as public-interest entities such as undertakings that are of significant public relevance because of the nature of their business, their size or the number of their employees (Article 2.1 Directive 2013/34/EU).

27. It is expected that the Directive will affect approximately 6,000 companies and groups across the EU. By April 2014 fewer than 10\% (approximately 2,500) of the largest European companies had reported non-financial information regularly, even though there were some provisions -unclear and ineffective- in the Directive 2013/34/EU requiring them to do so.

28. Reasons vary as to why the Directive channels its efforts towards these undertakings and not towards small and medium companies. Among these is the EU's intention to reduce the overall regulatory burden that companies bear. In particular, the EU intends to alleviate the bureaucratic burden of small and medium-sized enterprises ('SMEs') ${ }^{54}$ in order to improve the business environment for SMEs and to promote their internationalization ${ }^{55}$. This is coherent with the 'think small first' principle. Additionally, it must be noted that large companies have broader supply chains than SMEs. The impact of the Directive will be, therefore, higher and its implementation easier with larger companies, the subsidiaries of which will be exempted if they are included in the consolidated management report.

29. According to Whereas 14 of the Directive, this limitation of the personal scope of application of the Directive does not prevent member States from requiring disclosure of non-financial information from other kinds of undertakings.

30. A comparison of the subjective element of the Directive on the one hand, and that of the 2010 California Transparency in Supply Chains Act ('CTSCA') and the UN GPs on the other is relevant ${ }^{56}$.

53 Global Reporting Initiative, G4 Sustainability Reporting Guidelines, online publication. Available at https://www. globalreporting.org/resourcelibrary/GRIG4-Part1-Reporting-Principles-and-Standard-Disclosures.pdf (accessed on 3 January 2017), Preface.

54 European CounciL, Conclusions, 24 and 25 March 2011, CO EUR 6 CONCL 3.

55 European Commission, "Europe 2020 A strategy for smart, sustainable and inclusive growth", COM (2010) 2020.

56 There exist comparable European laws to the Directive. Nevertheless we deem that this American law provides a better contrast due to its different approach and solutions. European examples include: in the UK, though with a different scope, deliberations pivot on the 26 March 2015 Modern Slavery Act; in Denmark prior to the Directive, § 99 a of the Danish Financial Statement Act was amended on $12^{\text {th }}$ June 2012 by the Act on the Creation of a New Mediation and Grievance Mechanism for Responsible Business Conduct so that businesses expressly account for the topic human rights and climate impact reduction in the management review; in Norway CSR issues reporting, including human rights, is mandatory as provided for in amended $\S$ 
31. The CTSCA requires the following elements in its target companies: a specific activity (retail sellers or manufacturers), a territorial connection (doing business in California) ${ }^{57}$ and a minimum size (gross receipts that exceed $\$ 100,000,000$ ). The UN GPs demand respect for human rights from all enterprises regardless of their size, sector, operational context, ownership and structure. The UN GPs point out that some SMEs can cause severe human rights impacts regardless of their size, the severity of which ought to be judged by the scale, scope and irremediable character. Nevertheless, the UN GPs also mention that the means through which an enterprise should fulfil its human rights responsibilities may also vary depending on whether, and the extent to which, it conducts business through a corporate group or individually.

32. Moreover, it is important to take into account that the repercussion of the contents of the Directive may go further than their initial scope and affect large companies beyond the Directive's reach. There are reasons for believing so. For example, the Trans-Atlantic Trade and Investment Partnership (TTIP) currently being discussed could eventually lead to an approximation of the EU and US rules on some regulatory issues affecting trade and business, including reporting duties. Trans-Atlantic regulatory uniformity could have a very significant impact on world companies standing beyond the legal scope of a potential unified regulation due to the international weight of a combined US-EU regulation. Bearing in mind that uncoordinated regulations challenge multinational corporations and keep small and medium-sized business from entering new markets altogether ${ }^{58}$, it is reasonable to expect that if the TTIP is finally signed, transparency measures such as the Directive will be coordinated and set a reference standard ${ }^{59}$.

\section{Obligations of the companies}

33. The fundamental obligation established by the Directive is a reporting duty on non-financial issues. This is no conceptual innovation. Article 46 (1) (b) of Directive 78/660/EEC as modified by Directive 2003/51/EC on the annual and consolidated accounts of certain types of companies provided that, where appropriate and to the extent necessary for an understanding of the company's development, performance or position, the annual report shall also contain non-financial information, including information relating to environment and employee matters. But very few companies adopted transparency commitments as a result of that indication. The original wording of Article 19 of Directive 2013/34/EU, prior to modification, contained a similar provision requiring the inclusion of non-financial information only "where appropriate" .

34. The Directive follows a 'pursue or explain' strategy and combines voluntary and mandatory dispositions. The only obligation added by the new Directive is "to include in the management report a non-financial statement containing information to the extent necessary for an understanding of the undertaking's development, performance, position and impact of its activity, relating to, as a minimum, environmental, social and employee matters, respect for human rights, anti-corruption and bribery matters, including:

a) a brief description of the undertaking's business model;

b) a description of the policies pursued by the undertaking in relation to those matters, including due diligence processes implemented;

3.3 of the Norwegian Accounting Act, and; in France: (i) prior to the enactment of the Directive, § L.225-102-1 of the Commercial Code as amended by the Loi $\mathrm{n}^{\circ}$ 2010-788 of 12 July 2010 (Loi Grenelle II) and its 26 April 2012 implementation decree, requires human rights issues reporting; (ii) prior to the enactment of the Directive $\S 8$ of the Loi $n^{\circ} 2014-773$ of 7 July 2014 on the guidance and programming of development and international solidarity policy requires that corporations establish risk management procedures in order to prevent human rights abuses.

57 In the sense of Revenue and Taxation Code Section 23101.

58 T. J. BOLlYky / A. BRADFURD, op. cit., p. 2.

59 In fact, eighty (80) percent of the potential economic gains from the TTIP agreement depend on reducing the conflicts and duplication between their rules (BOLlYKy / BRADFord, op. cit., p. 1).

60 European Commission, "Proposal for a Directive of the European Parliament and of the Council, amending Council Directives 78/660/EEC and 83/349/EEC as regards disclosure of non-financial and diversity information by certain large companies and groups", COM (2013) 207 final. 
c) the outcome of those policies;

d) the principal risks related to those matters linked to the undertaking's operations including, where relevant and proportionate, its business relationships, products or services which are likely to cause adverse impacts in those areas, and how the undertaking manages those risks;

e) non-financial key performance indicators relevant to the particular business."

35. This obligation is a duty of mere disclosure. The Directive does not impose any direct requirement to undertake a human rights policy, save the clause establishing that if the company "does not pursue policies in relation to one or more of those matters, the financial statement shall provide a clear and reasoned explanation for not doing so". This obligation contains an obligation to disclose at least the description of the business model and the detection of the risks ${ }^{61}$.

36. The Directive does not provide a mechanism ensuring that the explanations are clear and reasoned. This could be a crucial issue, as shown by the corporate governance reporting experience. In relation with this, the "Study on Monitoring and Enforcement Practices in Corporate Governance in the member States" ${ }^{\prime 2}$ underlined the poor quality of the explanations offered by companies when departing from their corporate governance codes. This is the reason why a large majority of respondents to the 2011 Green Paper on EU corporate governance framework ${ }^{63}$ were in favour of requiring companies to provide better explanations for departing from codes' recommendations. Some national guidelines require tighter standards in this respect. The European Commission has drafted a recommendation on the quality of corporate governance reporting. It contains specific provisions on the quality of the explanations in case of departure from the codes. According to this recommendation, companies should clearly state which specific recommendations they have departed from and, for each departure from an individual recommendation: a) explain in what manner the company has done so; b) describe the reasons for the departure; c) describe how the decision to depart was taken within the company; d) where the departure is limited in time, explain when the company envisages complying with a particular recommendation; e) where applicable, describe the measure taken instead of compliance and explain how that measure achieves the underlying objective of the specific recommendation or of the code as a whole, or clarify how it contributes to good corporate governance of the company. The information should be sufficiently clear, accurate and comprehensive to enable shareholders, investors and other stakeholders to assess the consequences arising from the departure from a particular recommendation. It should also refer to the specific characteristics and situation of the company, such as size, company structure or ownership or any other relevant features. Explanations for departures should be clearly presented in the corporate governance statement in such an accessible way for shareholders, investors and other stakeholders. This could be done, for example, by following the same order of recommendations as in the relevant code or by grouping all explanations for departure in the same section of the corporate governance statement, as long as the method used is clearly explained ${ }^{64}$. The same problem will have to be addressed in relation with the explanations mentioned in the Directive.

37. The Directive allows a broad margin of discretion to member States to specify the extension of the disclosure duty. The minimum content of the transparency requirement is the one established in letters a) to e) mentioned above. Beyond these, the terms are vaguer: "to the extent necessary for an understanding".

61 European Coalition for Corporate Justice, "EU Directive on the disclosure of non-financial information by certain large companies online publication", 2014. Available at http://www.corporatejustice.org/On-15-April-2014-the-European.htm1?lang=en (accessed on 3 January 2017).

${ }^{62}$ RiskMetrics Group, "Study on Monitoring and Enforcement Practices in Corporate Governance in the Member States", Contract No. ETD 2008/IM/F2/126, 2009.

63 European Commission, Green Paper "The EU corporate governance framework”, COM (2011) 164 final.

64 European Commission, Commission Recommendation of 9 April 2014 on "the quality of corporate governance reporting ('comply or explain')”, European Commission document 2014/208/EU. 
38. In coherence with the UN GPs, the Directive also provides an 'emergency exit' clause ${ }^{65}$ that allows for information relating to impeding developments or matters in the course of negotiation to be omitted in exceptional cases involving a serious disadvantage to the commercial position of corporations.

39. Another manifestation of the flexibility of the Directive is the fact that it does not impose the reporting framework to be used by corporations; it allows them to opt for a national, Union-based or international framework. This is consistent with the Preamble's flexibility in this regard: "allowing for high flexibility of action, in order to take account of multidimensional nature of CSR and the diversity of the CSR policies implemented by business".

40. As pointed out, it must be borne in mind that "the publication of a sustainability report can be viewed as effective if the sustainability-related information provided in the report forms the basis for meaningful interaction between the company and its internal and external stakeholders. (...) Given the context-specific nature of sustainability, we would expect different companies and stakeholders groups to focus on different sustainability-related priorities"66.

41. But the above-mentioned flexibility should be compatible with providing sufficient comparative standards that meet the needs of investors and other stakeholders. Comparability is one of the most important principles of the Directive, as it is in the Global Reporting Initiative. In its G4 Global Sustainability Reporting, the Global Reporting Initiative asserts that the information should be presented in a manner that enables stakeholders to analyse changes in the organization's performance over time, and which could support analysis relative to other organizations.

42. By 6 December 2016, upon consultation with relevant stakeholders, the Commission will prepare "non-binding guidelines on methodology for reporting non-financial information, including non-financial key performance indicators, general and sectorial, with the view to facilitating relevant, useful and comparable disclosure of non-financial information by undertakings". This is consistent with Principle $3 \mathrm{c}$ ) of the UN GPs that provides that in meeting their duty to protect, states should provide effective guidance to business enterprises on how to respect human rights throughout their operations.

43. As mentioned, the statement will normally be incorporated into the management report. Nevertheless, member States may allow for a separate report if published in conjunction with management reports in accordance with the publicity requirements of Directive 2013/34/EU or if the separate report "is made publicly available within a reasonable period of time, not exceeding six months after the balance sheet date, on the undertakings website, and is referred to in the management report".

44. This aspect of the Directive may be compared with the CTSCA. The CTSCA is also based on the combination of a modest legal obligation with a broad flexibility of performance for the companies subject to it. The main common point between the Directive and the CTSCA is that none of them establishes direct obligations. However, although the Directive follows the same smart mix concept idea, the CTSCA and the Directive differ in the delimitation of their areas of concern. While the CTSCA focuses on the eradication of slavery and human trafficking, the Directive focuses on environmental, social and employment matters, respect for human rights, anti-corruption and bribery matters. The CTS$\mathrm{CA}$ addresses more peremptory issues. While the goal of the Directive is closer to the development of a sustainable economy, the CTSCA is more concerned with the prevention of human rights crimes, a fact that could be regarded as a paradigm shift because up until that moment the private sector had no role in combating human trafficking ${ }^{67}$.

65 European Coalition for Corporate Justice, op. cit.

66 R. Barkemeyer / L. Preuss / L. Lee, “On the effectiveness of private transnational governance regimes - Evaluating corporate sustainability reporting according to the Global Reporting Initiative”, Journal of World Business, No. 50, 2015 , p. 314.

67 J. Todres, "The Private Sector's Pivotal Role in Combating Human Trafficking”, California Law Review, No. 3, 2012, p. 190. 
45. Further, due to the fact that the CTSCA deals primarily with supply chain concerns, it may be understood that the CTSCA contains a higher extraterritorial vocation than the Directive and its impact will be, therefore, more powerful in other countries.

46. Both the CTSCA and the Directive coincide in enumerating a minimum of disclosure requirements in relation with the matters mentioned, but the CTSCA is more concrete in defining these minimums: verification of product supply chains to evaluate and address risks; conducting audits to evaluate supplier compliance with company standards; requiring direct suppliers to certify that materials incorporated into the product comply with the laws; internal accountability standards and procedures for employees or contractors failing to meet standards, and; providing employees and management who have direct responsibility for supply chains training on these matters particularly with respect to mitigating risks.

47. It is relevant to note that the CTSCA requires companies to disclose "to what extent, if any" the mentioned points are dealt with. This wording implies that companies shall provide details of its performance ${ }^{69}$. But at the same time it means that not performing any action on a specific point is not a breach of the law.

48. There exist significant differences between the Directive and the CTSCA in the disclosure mode. Under the CTSCA the disclosed information shall be posted on the corporation's "Internet Web site with a conspicuous and easily understood link to the required information placed on the business's homepage" ${ }^{\text {" }}$. In the unlikely event that the corporation does not have an internet web site, "consumers shall be provided the written disclosure within 30 days" of receiving a request from a consumer. The publication in the website makes it easier for consumers - not only the ones in California but also worldwide consumers- to access to the information. In the case of the Directive, it is likely that only NGOs taking the time to consult the management report will make the disclosure made in the management report known to the general public.

\section{Monitoring the fulfilment of the obligations}

49. Member States have the obligation to ensure that the statutory auditor or audit firm checks whether the non-financial statement has been provided. This is a compulsory control mechanism providing for the effective accomplishment of the Directive's disclosure obligation. Notwithstanding this, the most interesting provision is the one stating that member States may require that the information "be verified by an independent assurance services provider". This could be the key to the efficacy of the Directive. Indeed, it is very important to ensure that the information will be reliable. Some member States' laws foresee criminal liabilities for directors who falsify annual accounts or other documents that record the legal or financial status of a company when a financial damage to shareholders or partners or to third parties is caused (Article 290 of the Spanish Criminal Code). Should these provisions include non-financial statements?

50. Along these lines, the Directive requires member States to impose collective responsibility and liability for members of the administrative, management and supervisory bodies of an undertaking acting within the competence assigned to them by national law to ensure that management reports (among other documents) are drawn up and published in accordance with the requirements of Directive 2003 as modified (Article 33 of Directive 2013/34/EU as amended). However, the Directive excludes from the auditing requirements of the management report the non-financial statement (Article 34 of Directive 2013/34/EU as amended).

\footnotetext{
${ }^{68}$ Section 3 (c).

69 J. Todres, op. cit., p. 190.

70 Section 3 (b).
} 
51. The only possible intervention of the public authorities in the functioning of the CTSCA could be that of an action of injunctive relief brought by the Attorney General if one of the listed companies does not fulfil its obligation to disclose. Contrary to what is foreseen in the Directive, under the CTSCA companies have no obligation to explain why no policy has been adopted, they must only disclose the fact that they have failed to adopt any policy.

\section{Assessment}

52. Although the Directive does not create direct obligations on companies beyond the reporting one, and although the Directive still needs national transposition in order to be effectively implemented, areas of improvement can be detected taking into consideration the principles set by the UN GPs and the very objectives and principles settled in the Directive's preamble.

53. Firstly, the 'flexibility' issue. One of the principles informing the Directive -Whereas 3 of the Directive- is the flexibility of action. This is consistent with the UN GPs, which recognize that communication can take a variety of forms, including the formal reporting itself, the stipulations of which should take into account variations in the size and structures of companies.

But this flexibility may affect negatively the minimum level of comparability the Directive aims at; for instance, flexibility leaves room for adjustments and more favourable ways of presenting a company's non-financial performance ${ }^{71}$. As one of the goals of the Directive is to provide consumers and investors with information allowing them to compare the behaviour of companies, excessive flexibility in reporting may lead to non-comparable reports, thereby frustrating the mechanics foreseen by the Directive-consumers and investors rewarding or punishing companies based on information comparable enough to inform their responsible decisions. The alternative, however, should not be total uniformity, but a solution that enables "internal and external stakeholders to meaningfully interact with the respective comparison the basis of the information provided in these reports"72.

54. Secondly, the risks associated with the expression "where relevant and proportionate". As already pointed out, the interpretation of this expression is problematic ${ }^{73}$ for accuracy and trustfulness in reporting may be avoided taking advantage of the vagueness of this expression.

55. Thirdly, the mention in the UN GPs requiring that companies provide information that is sufficient to evaluate the adequacy of an enterprise's response to the specific human rights impact involved should complement the Directive's requirements. When transposing the Directive, member States should establish a mechanism ensuring that companies fulfil this obligation. Member States could further require that the information provided by companies be verified in cases of severe human rights impact. An independent verification of human rights reporting could strengthen the information's content and credibility. This is essential to achieve an effective impact on stakeholder's decisions.

56. Fourthly, consumer access to information. Further to the formal reporting obligation, a provision similar to that of the CTSCA requiring online access would facilitate the public's access to reports. As currently foreseen in the Directive, individual consumer access to reports is not as easy as it would be, were there a visible link on the website of companies.

57. The shortcomings mentioned above may jeopardize the ability of the Directive to generate transparency and stakeholder engagement, a hindrance that could lead companies to produce "strategic disclosure designed to protect their legitimacy rather than paint a complete picture" "74 and hinder com-

${ }^{71}$ S. KNeBel / P. SeELe, "Quo vadis GRI? A (critical) assessment of GRI 3.1 A+ non-financial reports and implications for credibility and standardization”, Corporate Communications: An International Journal, No. 20(2), 2015, p. 197.

72 R. Barkemeyer, L. Preuss / L. Lee, op. cit., p. 324.

73 European Coalition for Corporate Justice, op. cit.

74 D. Hess, "Social Reporting and New Governance Regulation: the Prospects of Achieving Corporate Accountability through Transparency”, Business Ethics Quarterly, No. 17(3), 2007, p. 455. 
panies' capacity to demonstrate their strong commitment to human rights in comparison with that of their competitors ${ }^{75}$.

58. When transposing the Directive, member States should tackle the shortcomings already mentioned by the European Coalition for Corporate Justice, such as the lack of an explicit requirement to report on on-going impacts and incidents, or the need for a clearer explanation of the criteria for determining 'principal risks' ${ }^{76}$.

\section{Conclusion}

59. The purpose of this article is to provide a European viewpoint on the subject of business-human rights by means of analysing what may be conceived as a development tool: the Directive. The approach is a balanced one. Greater development awareness is offered to legally oriented readers while for development-oriented readers a legal introduction is depicted.

60. Regarding the development and human rights protection telos of the Directive, two issues are raised. The first one touches upon the aptness of the Directive from the viewpoint of the development needs of the countries to which it affects. The suggestion that the reporting of the Directive should be done considering the particularities of the societies affected by corporations and the broader structural impact of corporations is put forward. The second issue touches upon the fact that the Directive is rooted in one of the various existing narratives on the business-human rights relationship. The fact that multiple conflicting narratives exist on the relationship between business and human rights needs to be understood in order to grasp the specificity of the Directive within the wider context.

61. Regarding the legal commentary on the Directive, a description of the basic legal aspects is coupled with several improvement proposals. The content of the reporting obligation of the Directive risks being too vague and one hindering comparability. The CTSCA is used as a mirror to suggest potential improvements in this respect. Furthermore, it is suggested that a more stringent audit on the actual content of the disclosure reports could be a key factor contributing to the attainment of the human-rights aim of the Directive.

\footnotetext{
75 D. Hess, op. cit., pp. 461-462.

76 European Coalition for Corporate Justice, op. cit.
} 